\section{A espiritualidade estético-erótica de Rubem Alves*}

\author{
Carlos Caldas ${ }^{a}$ \\ Pontifícia Universidade Católica de \\ Minas Gerais, Brasil \\ http:/ / orcid.org/0000-0003-0472-7250
}

RECEBIDO: 23-03-17. APROVADO: 22-08-17

Resumo: Espiritualidade, entendida como busca do transcendente e vivência pessoal do que se constitui no objeto da fé, é fundamental em qualquer manifestação religiosa. No caso do cristianismo, em todos os seus principais ramos (Catolicismo Romano, Ortodoxia Oriental e Protestantismo), a espiritualidade tem importância que dificilmente poderá ser exagerada. Rubem Alves (1933-2014), um dos mais complexos e criativos pensadores que o protestantismo brasileiro produziu, inovou por completo a compreensão da espiritualidade, entendendo-a a partir de uma perspectiva erótica, isto é, do prazer, e pela experiência da estesia estética. $\mathrm{O}$ presente artigo pretende apresentar alguns elementos desta compreensão alvesiana de espiritualidade.

Palavras-chave: Rubem Alves; estética; espiritualidade; poesia; prazer.
The Aesthetic-erotic Spirituality of Rubem Alves

Aвstract: Spirituality, understood as the search for the transcendent, and the personal experience of what constitutes the object of faith, is a fundamental tenet in any religious tradition. In the case of Christianity, in all its main branches (Roman Catholicism, Eastern Orthodoxy, and Protestantism), the importance of spirituality cannot be exaggerated. Rubem Alves (1933-2014), one of the most complex and creative thinkers that Brazilian Protestantism has produced, completely innovated the knowledge of spirituality, understood it from an erotic perspective, that is, a perspective of delight, and by the aesthesis-aesthetics experience. This paper intends to present some elements of this Alvesian understanding of spirituality.

Key Words: Rubem Alves; Aesthetics; Spirituality; Poetry; Delight.

\section{COMO CITAR:}

Caldas, Carlos. "A espiritualidade estético-erótica de Rubem Alves". Theologica Xaveriana 186 (2018): 1-19. https://doi. org/10.11144/javeriana.tx68-186.aeera

\title{
Reconhecimento
}

Este artigo é atividade do Grupo de Pesquisa "Religião, pluralismo e diálogo" do Programa de Pós-Graduação em Ciências da Religião da PUC Minas (Pontifícia Universidade Católica de Minas Gerais). Este Grupo de Pesquisa está alocado na Linha de Pesquisa Pluralismo, Imaginário e Sociedade, PIS.

${ }^{*}$ Artigo de pesquisa

aAutor de correspondência. Correio eletrônico: crcaldas2009@hotmail.com 
No inferno, segundo Dante, não há nem esperança nem riso. No purgatório não tem riso, mas há esperança. No céu, a esperança já não é necessária, e reina o riso. Harvey Cox

\section{Aclarando conceitos básicos: fé - religião - espiritualidade}

"Que é o homem?” (Salmo 8,4). Esta pergunta feita por um poeta anônimo do antigo Israel é a "pergunta geradora" de toda reflexão antropológica. Ao longo dos séculos, muitas respostas têm sido oferecidas para esta pergunta. O ser humano - אָָ adam em hebraico, é conhecido como homo sapiens (literalmente, "homem sábio"), por conta de sua capacidade de formular raciocínios, partir do conhecido para o desconhecido, estabelecer ligaçóes entre ideias, criar conceitos abstratos. Mas o adjetivo sapiens não dá conta da complexidade do que significa ser humano. Somos também homo faber, aquele que fabrica instrumentos e ferramentas, e com estes modifica a natureza, criando desta maneira a cultura, somos homo ludens ${ }^{1}$, aquele que brinca e se diverte, homo xeconomicus, aquele que cria relaçôes de produção e consumo distintas de outras atividades e dimensões da vida.

Além destas adjetivaçôes, que são apresentadas apenas como exemplos, sem nenhuma pretensão de exaustividade, há que se lembrar também que, enquanto humanos somos homo religiosus, aquele que se preocupa com o transcendente, com o maravilhoso, com o inefável, com o numinoso, aquilo que está acima e além do que é perceptível aos sentidos físicos. Esta última possibilidade de adjetivação é a que mais de perto interessa aos objetivos do presente artigo.

O humano, enquanto homo religiosus, é marcado pela fome, sede, vontade de se encontrar com o transcendente, de ter algum tipo de experiência com a dimensão espiritual da existência. Neste sentido, o humano é caracterizado por ter fé, que no dizer do desconhecido autor do texto neotestamentário conhecido de maneira popular, mas errônea, como Epístola aos Hebreus, é "a certeza das coisas que se esperam, a convicção de fatos que se não veem” $(11,1)$. A fé é individual, e faz parte da condição do ser religiosus. antropologias que não levam em conta a dimensão da fé em seus esforços de interpretação do ser humano serão reducionistas. Logo, suas leituras do mistério que constitui o ser humano, por mais competentes e lúcidas que sejam em seus focos de atenção, não serão completas, pois jamais se entenderá o humano excluindo-se desta busca de compreensão o elemento espiritual propriamente.

\footnotetext{
${ }^{1}$ A compreensão do elemento lúdico como constitutivo irredutível do que significa ser humano foi desenvolvida pelo historiador holandês Johan Huizinga em Homo ludens. O jogo como elemento da cultura.
} 
Surge daí a religião, entendida como esforço comunitário de organização e sistematizaçáo de crenças, ensinamentos, doutrinas, narrativas mitológicas, rituais, costumes, ordens e proibiçõos ${ }^{2}$. Enquanto a fé é individual, a religião é social. Vista de uma perspectiva utilitarista, a religiāo pode ser entendia como um dos elementos definidores da identidade cultural de um grupo humano (assim como a língua falada por este grupo). Em perspectiva individual, a religiáo pode ser entendia como elemento de valia para conferir valor existencial e sentido para a vida.

É exatamente da individualidade da fé que surge a necessidade de se estabelecer diferença entre os conceitos de religiāo e espiritualidade: religiáo pode ser em alguns casos apenas uma afiliaçấo sem compromisso ou envolvimento de vida, enquanto a espiritualidade é a busca consciente de uma experiência profunda e rica de sentido com o espiritual, o transcendente.

A palavra espiritualidade (derivada do latim spiritualitas) tem estado muito em voga nos últimos anos, tanto em termos de senso comum como na literatura especializada, em estudos de religiáo e em teologia. Praticamente todas as expressóes religiosas têm suas expressóes de espiritualidade Por isso, o foco do presente artigo não é falar de espiritualidade em geral, mas especificamente no ambiente da tradição judaico-cristá, na qual Rubem Alves, o objeto propriamente de estudo do artigo se insere.

Quanto à espiritualidade, pode-se dizer que "[o] conceito moderno de espiritualidade tem sua origem na palavra francesa spiritualité, que, desde o século VII, no âmbito da teologia das ordens religiosas católicas francesas, é termo técnico para a relação pessoal com Deus e a vivência da fé"3.

Tem sido comum falar-se de espiritualidade em oposição à religiosidade, especialmente em tempos de um virtual esgotamento de maneiras de vivenciar a fé se esta estiver atrelada a qualquer tipo de vinculaçâo institucional. Daí falar-se em pessoas que vivenciam espiritualidade, mas que não têm necessariamente uma prática de religiosidade. Pelo menos não em termos formais e institucionais. Neste sentido, não é demais repetir, espiritualidade é algo comum a todas as expressóes religiosas. Eis aí evidência que aponta para o fato que há no ser humano uma forte sede do transcendente, do metafísico, do que está acima e além do que os sentidos físicos são capazes de perceber.

Interessante um olhar para a palavra espiritualidade em perspectiva etimológica. As palavras deste campo semântico - espirito, espiritual, espiritualidade-derivadas da raiz latina spiritu, usada na Vulgata para traduzir o substantivo feminino hebraico

\footnotetext{
${ }^{2}$ Esta listagem de características do que constitui a religião é baseada em Smart, Dimensions of the Sacred. An Anatomy of World's Beliefs.

${ }^{3}$ Butzke, "Espiritualidade in Bortoletto Filho", 387.
} 
רוּ (ruach), que por sua vez foi traduzido pela Septuaginta pelo substantivo masculino $\pi v \varepsilon \tilde{u} \mu \alpha$ (pneuma). Curiosa e coincidentemente, tanto no hebraico como no grego as palavras significam "vento" ou "respiração". Logo, sendo espiritualidade uma palavra derivada de espírito, adquire a conotação de uma realidade vivencial, tâo essencial à vida quanto a respiração. A literatura paulina usa o adjetivo $\pi v \varepsilon v \mu \alpha \tau \iota \kappa \tilde{\omega} \varsigma$ (pneumatikós) para se referir à pessoa em quem o Espírito de Deus habita (ex., 1Co 2.14-15)4. A este respeito, Mark A. McIntosh, estudioso do tema do misticismo cristão, esclarece:

Espiritualidade, em outras palavras, não é algo que o crente tem, mas é um novo padrão de crescimento pessoal que acontece na comunidade dos que foram buscados, convertidos e amados pelo Cristo ressurreto.

[...] o espiritual está ligado à presença ativa de Deus, e não primariamente a experiências interiores extraordinárias, ainda que a presença de Deus possa certamente despertar tais sentimentos. Logo, a espiritualidade neste sentido não está ligada ao cultivo de experiências íntimas particulares, mas com a nova rede de relacionamentos comunitários e percepçôes que a presença de Deus torna possíveis para cada pessoa espiritual. ${ }^{5}$

Houve, há e haverá na tradição cristã uma pletora de compreensôes do que significa espiritualidade e, via de consequência, grande variedade de possibilidades de vivência(s) da espiritualidade. De fato, ao longo dos séculos, diferentes modelos cristãos de espiritualidade foram desenvolvidos. Paulo Afonso Butzke menciona as seguintes formas históricas da espiritualidade cristá: ascético-monástica, bíblico-meditativa, místico-contemplativa, e, no seio do protestantismo, a espiritualidade pietista, a fundamentalista, a carismática, e a da libertação ${ }^{6}$.

Esta introdução procurou apresentar em termos bíblicos e histórico-sistemáticos, uma síntese do que a tradição cristã ocidental entende por espiritualidade. Tendo uma compreensão, posto que mínima, deste conceito, pode-se prosseguir apresentando o objetivo do presente artigo, a saber, a compreensão de espiritualidade em Rubem Alves. Antecipando uma conclusão, pode-se afirmar que Alves, com sua espiritualidade

\footnotetext{
${ }^{4}$ Curiosamente, a palavra aparece apenas duas vezes no Novo Testamento. A outra referência encontrase em Ap 11,18. Mas seria enganoso concluir que a pouca quantidade de referências aponta para uma não importância do tema na teologia do Novo Testamento. Melhor seria concluir que os escritores neotestamentários não pensam em termos platônicos de distinção entre espiritual e terreno, sendo esta última realidade inferior à primeira. Assim, na perspectiva do Novo Testamento o todo da vida "material" é revestido de caráter espiritual. Esta seria uma consequência da encarnaçáo do Logos: a partir do momento que o Verbo assume a natureza humana, não há mais distinção entre "espiritual" e "material".

${ }^{5}$ McIntosh, Mystical Theology, 6-7.

${ }^{6}$ Butzke, "Espiritualidade in Bortoletto Filho", 387-390. Há que se fazer uma correção à elaboração de Butzke no sentido de reconhecer que há versóes católicas de espiritualidades de modelo fundamentalista, carismática e da libertação.
} 
aqui denominada de estético-erótica, criou um modelo alternativo de compreensão e vivência da espiritualidade sem qualquer paralelo, seja dos seus contemporâneos, seja dos seus antecedentes e das suas fontes (in)formadoras e influenciadoras. Mas antes será apresentada, ainda que apenas em síntese, a trajetória intelectual de Alves para, na sequência, apresentar o que se constitui no coração do presente artigo, isto é, sua própria elaboração de espiritualidade.

\section{A trajetória de Rubem Alves}

O presente artigo trabalhará a partir das seguintes hipóteses operacionais:

1. A primeira é a aceitação da afirmação que de fato, em seus últimos textos Rubem Alves rompe com aspectos acadêmicos formais e com as regras de escrita do trabalho científico. Ele assume com indisfarçável ponta de orgulho este ponto no prefácio de Variaçôes sobre o prazer (Santo Agostinho, Nietzsche, Marx e Babette) quando diz:

Esclarecimento: neste livro não haverá notas de rodapé. Rodapé é coisa que fica por baixo, na altura do pé, e é incômodo ficar olhando para baixo. Assim, como estou escrevendo este livro sob uma inspiração culinária e gastronômica, incluirei, no meio do texto, "notas de canapé", coisas pequenas e saborosas, algumas doces, outras, apimentadas, que abrem o apetite...?

2. A segunda é que não houve propriamente uma mudança de discurso ou de ênfase no pensamento de Rubem Alves. Ideias defendidas em sua segunda fase, por assim dizer, que têm mais a ver com a estética que com a ética, já se encontram claramente expostas em alguns de seus primeiros trabalhos, no início dos anos de 1970.

3. A terceira é a contestação da afirmação que Alves em sua fase crepuscular tivesse abandonado a teologia. De maneira criativa, diferente, alternativa, que não se enquadra em nenhum padrão ou paradigma, Alves continuou a produzir teologia. Na verdade, ele nunca abandonou o pensamento teológico. O elemento simbólico, metafórico, sugestivo da linguagem teológico-religiosa jamais se descolou da literatura alvesiana. A Rubem Alves sem dúvida se aplica o jargão utilizado à farta nos idos da década de 1970, que dizia ser a teologia da libertação "um novo modo de fazer teologia".

Esta terceira hipótese é particularmente importante para os propósitos do presente artigo, que pretende demonstrar que Alves desenvolveu sua própria compreensão de espiritualidade, elemento absolutamente central na agenda et credenda do cristianismo.

\footnotetext{
${ }^{7}$ Alves, Variações sobre o prazer (Santo Agostinho, Nietzasche, Marx e Babette), 7.

${ }^{8}$ A expressáo "nova maneira de fazer teologia" foi utilizada por Clodovis Boff para se referir à teologia da libertação (Boff, Teologia e prática - teologia do político e suas mediaçōes, 21). Rubem Alves, ao utilizar como ferramentas auxiliares de sua reflexão teológica a filosofia da linguagem e a psicanálise, e ao propor uma teologia do corpo e o corpo em diálogo com o sagrado propôs "uma nova maneira de fazer teologia".
} 
Isto posto, pode-se prosseguir, apresentando síntese da trajetória intelectual e espiritual de Rubem Alves: Rubem Azevedo Alves (1933-2014), mineiro de Boa Esperança, regiáo sul do estado, foi um dos pensadores mais criativos e complexos que o protestantismo brasileiro jamais produziu. Sua formação se deu na área de teologia: graduação no Seminário Presbiteriano de Campinas (1957), mestrado no Union Theological Seminary de Nova Iorque (1964) e doutorado no Princeton Theological Seminary (1968). Ordenado pastor da Igreja Presbiteriana do Brasil, IPB, exerceu o pastorado em Lavras, no centro-oeste mineiro, de 1958 a 1963. Sua produção acadêmica era vasta, cobrindo áreas táo diversas como a teologia, os estudos de religiáo a educação, além de textos para crianças e um incontável número de crônicas, nas quais falava da vida e da existência com um equilíbrio raro entre profundidade, leveza, e facilidade de expressão. A respeito de Rubem Alves fiz a seguinte observação:

Dono de um texto a um só tempo leve e denso, ágil e profundo, Rubem Alves conseguia o que poucos conseguem - comunicar profundamente sem cair no lugar comum de obviedades e banalidades rasas. Era um intelectual de peso e medida, mas que resolveu escrever para todas as classes, e o fez com muito sucesso. Com isso atraiu a inveja e críticas amargas de muita gente. Criticado por seus pares da Igreja Presbiteriana do Brasil, que, não entendendo sua proposta nova, diferente e ousada de fazer teologia, e não concordando com sua militância no movimento ecumênico, tomaram-no como heresiarca, um maldito que deveria ser banido e esquecido. Criticado por católicos por ser protestante demais. Criticado por alguns partidários católicos hardcore da Teologia da Libertação por ser pouco marxista e muito pequeno-burguês. Criticado por filósofos da educação por não ter formação em pedagogia. Sem entrar no mérito se essas críticas procedem ou não, e, caso positivo, até que ponto procedem [...], observa-se que, se recebeu tantas críticas de segmentos táo diversos um do outro, é porque Rubem Alves foi provocador, instigante e não se contentava de modo algum em se limitar a reproduzir discursos estabelecidos como ortodoxos pelo status quo dominante. Ele se tornou um "intelectual público", mas não era um escritor de autoajuda. Muito longe disso. Ele era crítico, criativo, intuitivo, provocante, mas não era pedante. Por isso navegou com facilidade espantosa e rara em águas diversas como teologia, filosofia, pedagogia, poesia e psicanálise. ${ }^{9}$

Dentre suas obras mais conhecidas encontram-se Da esperança (a versão em português de sua tese de doutorado em teologia defendida no final dos anos de 1960 no já mencionado Seminário de Princeton, na qual propôs pioneiramente a expressão "teologia da libertação"), A gestação do futuro (versão em português de Tomorrow's

${ }^{9}$ Caldas, "A polifonia e o ipê-amarelo: anotaçóes sobre o 'primeiro' Rubem Alves como leitor de Dietrich Bonhoeffer", 271-272. 
Child $^{10}$ ), Protestantismo e repressãa $0^{11}$ (a versão de sua tese de livre-docência defendida na Universidade Estadual de Campinas, Unicamp), O que é religiāo, Variaçōes sobre a vida e a morte ou o feitiço herético-erótico da teologia, $O$ enigma da religião e $O$ suspiro dos oprimidos ${ }^{12}$, além de grande número de coletâneas com crônicas, publicadas em jornais como Folha de S. Paulo e o Correio Popular, de Campinas, sem embargo de menção das crônicas que publicou por anos em Tempo e Presença, o periódico do Centro Ecumênico de Documentação e Informação, CEDI, entidade na qual trabalhou por muitos anos.

Rubem Alves é um pioneiro na formulação do que posteriormente foi chamado de teologia da libertação latino-americana. Em "Sobre deuses e caquis", o prefácio que escreveu para Da esperança, a versão em português de sua tese de doutoramento em teologia em Princeton, Alves descreve na primeira pessoa do singular a história de sua "paternidade" da teologia da libertação:

E assim eu batizei esta tese/filha: Towards a Theology of Liberation ${ }^{13}$, nome que se encontra lá no original e no registro de direitos autorais ${ }^{14}[\ldots]$. Um editor católico se interessou pelo meu texto. Ele fez uma reserva apenas. O nome do livro era meio esquisito: libertação, nome sem respeitabilidade teológica, sobre que ninguém falava. $\mathrm{O}$ que estava na crista da onda era a teologia da esperança. E ele me sugeriu mudar o título, para entrar no debate. É sempre mais fácil pegar um trem que já está correndo que fazer um outro novo, a partir de nada... E assim ficou: A Theology of Human Hope (Washington, Corpus Books, 1969). E, com isto, o nome "Teologia da libertação" me escapou... Harvey Cox escreveu o prefácio. Generoso. Nunca me havia visto. Nada sabia a meu respeito. E o nome dele já era chave mágica que abria todas as portas teológicas. E foi assim que ele abriu o que outros quiseram trancar. ${ }^{15}$

Mas, tal como já observado, os teólogos da libertação mailine não concordavam em considerar Alves como um de seus pares nesta linha de produção teológica. A respeito, ele afirmou:

\footnotetext{
${ }^{10}$ A tradução literal seria Filho do amanhã. O livro trata de possibilidades escatológicas, de um amanhã diferente do hoje, um amanhã que poderá se tornar realidade, um amanhã diferente do atual, dominado por uma lógica de produção e consumo, do domínio dos poderosos sobre os fracos.

${ }^{11} \mathrm{O}$ livro foi republicado posteriormente (2005) com o título mais amplo em alcance de Religião e repressão.

${ }^{12}$ Alves, Da esperança (1978); idem, Tomorrow's Child (1972); idem, Protestantismo e repressão (1982); idem, O que é religiāo (1984); idem, Variaçôes sobre a vida e a morte ou o feitiço herético-erótico da teologia (2005); idem, O suspiro dos oprimidos (1987).

${ }^{13}$ A tradução literal seria Em direção a uma teologia da libertação.

${ }^{14}$ Tal se deu em 1967, ou seja, antes da publicação de Teologia de la liberación, de Gustavo Gutierrez.

${ }^{15}$ Rubem Alves, "Sobre deuses e caquis", 41-42.
} 
Não sei se os teólogos da libertação me considerariam como tal. Não me considero como sendo um, porque não trabalho no limite de categorias marxistas. No momento, retiro minha inspiração náo de sociólogos, políticos, ou economistas, mas da poesia. ${ }^{16}$

A teologia de Rubem Alves tem sido objeto de estudo de muitos pesquisadores, mormente os que se dedicam à investigação da história do pensamento cristão. Neste sentido uma pesquisa recente é Dal Corso ${ }^{17}$. O italiano Battista Mondin, observou que Alves era "discípulo de Harvey Cox"18. O teólogo estadunidense Harvey Cox (n. 1929), de tradição batista, em 1969 escreveu um livro de título curioso: The Feast of Fools (literalmente, $A$ festa dos bobos). Neste livro, publicado no Brasil em 1974 com o título $A$ festa dos folióes, Cox discute a festa como um locus teológico, produzindo assim uma criativa e original teologia do lúdico, do festivo e do cômico.

Neste sentido, as reflexôes de Cox aproximam-se das elaboraçóes de Alves quanto ao prazer e a alegria como possibilidades de vivência da espiritualidade. E enfrentou o mesmo tipo de questionamento apontado acima, de ser este tipo de reflexão teológica e vivência da espiritualidade como uma fuga da realidade ou uma alienaçâo de "tolos" (como sugerido no título). Cox com clareza comenta contrariamente a tal crítica, de uma maneira que certamente teria a concordância de Rubem Alves:

E vem daí a objeção ética. Há gente sensível, reclamando que a gargalhada não é resposta adequada à guerra, ao racismo, à fome, à injustiça. Só mesmo a dedicação e o sacrifico sérios poderão livrar um dia a terra dessas pestilências. E como têm razão! Mas acontece, como já demonstramos antes, que nem a seriedade, nem a dedicação é oposto da comicidade. O oposto do cômico é a necessidade trágica, e talvez, até, a resignação estoica. A sensibilidade cômica tem isso de poder rir dos que fomentam guerras e perpetuam fomes, ao mesmo tempo que dá duro para destroná-los. Antevê a queda deles, mesmo que seu poder pareça inabalável. O cômico, muito mais que o trágico, porque encendeia (sic) esperanças, impele a mais, não menos, participação na luta por um mundo justo. ${ }^{19}$

A observação de Mondin é importante, porque identifica uma fonte e uma inspiração importantes para a espiritualidade estético-erótica de Rubem Alves.

${ }^{16}$ Puleo, The Struggle is One. Voices and Visions of Liberation, 189. Este livro é uma coletânea de entrevistas feitas pela jornalista Mev Puleo a teólogos da libertação latino-americanos.

${ }^{17}$ Dal Corso, Rubem Alves. Collana pensiero teológico.

${ }^{18}$ Mondin, Os teólogos da libertação, 53. Interessante comparar esta afirmação de Mondin, quanto a Rubem Alves ter sido discípulo de Cox, considerando que o próprio Alves declara que até ter completado seu doutorado ele nunca se encontrara com Cox.

${ }^{19}$ Cox, A festa dos foliōes, 158-159. 


\section{Conforme Mondin,}

De Harvey Cox, Alves recebeu tanto a orientação teológica como o método, mas assumiu em ambos os casos uma posição crítica e pessoal. Quanto ao método, segue Cox na recusa da metafísica e no uso da pesquisa sociológica [...]. Relativamente à orientação teológica, Alves segue seu mestre primeiramente na fase da teologia da esperança, mas desenvolve uma ideia da esperança cristã francamente mais bíblica do que a do autor de $A$ cidade do homem. ${ }^{20}$

Há que se observar que, conquanto a proposta de espiritualidade de Alves seja virtualmente única, é uma proposta formulada contexto vivencial e existencial mais amplo da América Latina, contexto no qual o tema da espiritualidade é importante. Haja vista a proposta de uma espiritualidade da libertaçáo, como a sugerida por Gutiérrez, Galilea, Casaldáliga e Vigil ${ }^{21}$. A proposta de espiritualidade da libertação da teologia latino-americana também é uma abordagem criativa e original, que vem contribuir para o todo do pensamento cristão sobre o importante tema da espiritualidade.

Desta maneira, a espiritualidade estético-erótica de Alves surge como uma linha, por assim dizer, na espiritualidade latino-americana. Usando uma metáfora fluvial, o grande rio da espiritualidade cristá mundial é alimentado pelo afluente da espiritualidade latino-americana, que tem como caudais a espiritualidade da libertaçáo dos autores mencionados, e a espiritualidade estético-erótica de Rubem Alves.

\section{Espiritualidade como experiência do estético e do erótico no pensamento de Rubem Alves}

A espiritualidade de Alves é o que neste artigo é denominada de "espiritualidade estético-erótica”. Por estética entende-se não necessariamente uma espiritualidade da arte, mas do sentimento, da fruição. Por erótica entende-se não necessariamente o sexual, mas a dimensão lúdica da existência, a dimensão do prazer. A palavra erótica é uma espécie de termo técnico no corpus da vasta literatura alvesiana ${ }^{22}$.

\footnotetext{
${ }^{20}$ Mondin, Os teólogos da libertação, 53.

${ }^{21}$ Gutiérrez, Beber em seu próprio poço. Itinerário espiritual de um povo; Galilea, Espiritualidade da libertação; Casaldáliga e Vigil, Espiritualidade da libertação.

${ }^{22}$ Uma nota de caráter pessoal: em 1988, três anos após minha formatura em teologia no Seminário Presbiteriano do Sul, em Campinas (o mesmo seminário onde o próprio Rubem Alves havia se formado, cerca de trinta anos antes), graças a um amigo comum, encontrei-me com Rubem Alves que, à época, colocara à venda toda sua biblioteca de teologia. Comprei dele então seu exemplar de Christ and Time, a versão em inglês de Christus und die Zeit ("Cristo e o tempo"), o conhecido tratado de teologia do Novo Testamento escrito pelo teólogo luterano alemão Oscar Cullmann. Enquanto escolhia os livros, ele me disse: “....agora não quero mais saber de teologia, agora só quero ler livro erótico”. Neste contexto específico, a palavra tinha conotação sexual. Minha reação foi uma explosão de gargalhada, muito natural
} 
A espiritualidade de Alves envolve o jogo, o brinquedo, a contemplação da beleza, da natureza e da cultura, constituindo-se assim em uma espiritualidade que envolve estas duas dimensóes da existência, a estética e a erótica. Este elemento foi observado pelo teólogo mexicano Leopoldo Cervantes-Ortiz, estudioso do pensamento alvesiano: "Ele [Rubem Alves] evita como pode a palavra 'dever', e abusa de outra: 'prazer"”23.

Em sobre a vida e a morte ou ofeitiço herético-erótico da teologia ${ }^{24}$ Rubem Alves desenvolve, a partir da palavra variaçôes, que é termo técnico da música (que remete à experiência estética - auditiva - da arte musical), noçóes de uma espiritualidade erótica:

Você entende agora porque dissemos que o teólogo é bufâo? Quem sabe o segredo do nome sagrado, nome que não pode ser pronunciado, o nome de Deus, sabe que tudo o mais não pode ser sagrado. Tudo o mais é dádiva, graça, brinquedo... E é por isso que a boca que balbucia uma prece diante de Deus é a mesma boca que explode em riso perante os sinais de honra com que os homens tentam esconder suas vergonhas. O palhaço é a face alegre do mesmo que sacrifica, no altar...

O encontro com o sagrado... O riso que despedaça os ídolos...

E o mundo livre dos ídolos, se transforma em jardins dos prazeres: tudo é permitido, desde que o nome sagrado continue a ser invocado em silêncio e o ruído do riso continue a exorcizar demônios... E o trabalho, e o pão, e o vinho, e a dança, e as cançóes, e as carícias, e o vento, e os pássaros, e os lírios dos campos, e o cheiro dos romãs depois da chuva e da bem-amada antes do amor, e o descanso, e o sábado, e a utopia do Reino de Deus, e viu Deus que tudo era muito bom, e o seu coraçáo se alegrou vendo a alegria dos homens, a quem ele amou e criou, para a felicidade, a liberdade...

Mundo que é brinquedo...25

Todavia, estas ideias não são de modo algum exclusivas de um Rubem Alves maduro. Já em $A$ gestação do futuro ${ }^{26}$ Alves tem elaborações que serão mais tarde desenvolvidas em Variaçôes sobre a vida e a morte, sobre a importância da criança ${ }^{27}$,

e espontânea, por perceber que ele queria brincar com um jovem pastor presbiteriano do interior de Minas, tal como ele mesmo o fora. Mas não custa repetir que no presente artigo, a palavra "erótica" tem conotação de prazer em sentido mais amplo que o do sexual conforme compreendido pelo senso comum.

${ }^{23}$ Cervantes-Ortiz, A teologia de Rubem Alves: poesia, brincadeira e erotismo, 17.

${ }^{24}$ Este livro tem dois subtítulos, um na capa, outro, em sua folha de rosto. Na capa, o subtítulo é $O$ feitiço erótico-herético da teologia, enquanto na folha de rosto é $A$ teologia e sua fala.

${ }^{25}$ Alves, Variaçôes sobre a vida e a morte ou of feitiço herético-erótico da teologia, 123.

${ }^{26}$ No prefácio à edição brasileira deste texto, seu tradutor, João Francisco Duarte Junior, esclarece que o livro foi escrito por Rubem Alves em 1971, período em que ele fora contemplado com uma bolsa de pesquisa concedida pelo Union Theological Seminary, de Nova Iorque.

${ }^{27}$ A partir de uma tragédia familiar - o nascimento de Raquel, sua filha caçula, com um defeito congênito grave, uma fissura completa entre o lábio e o palato (céu da boca), que fez com que ela fosse submetida a muitas cirurgias reparadoras. Rubem Alves começou a inventar estórias para tranquilizar sua filha, 
do brincar, do lúdico, do prazer na vivência da espiritualidade. Alves desenvolve uma espiritualidade que leva às últimas consequências um conhecido dito de Jesus: "Em verdade vos digo que, se não vos converterdes e não vos tornardes como crianças, de modo algum entrareis no reino dos céus" (Mt 18,3).

Consequentemente, explorará uma teologia estética do prazer, que servirá de base à sua espiritualidade erótica. Esta teologia do prazer é em si uma crítica à sociedade regida pela lógica do poder, da produção e do consumo. Como reação a isto, Rubem Alves desenvolve uma espiritualidade na qual as crianças ensinam aos adultos, a espiritualidade do jogo, do prazer da brincadeira, que subverte as regras do poder do mundo de quem "amadureceu":

O que é uma criança? O que, para ela, define as regras do jogo? O mito da pureza e da inocência das crianças de há muito está morto. As crianças não são puras. Sequer sabemos o que pureza significa. E também não são plenas de amor. O que caracteriza uma criança? Gostaria de fazer uma sugestão, não mais que uma sugestão. Concordo com a antropologia bíblica em sua indicação de que o homem deve ser compreendido através daquilo que faz. Sua atividade define a sua humanidade. Se isto for verdadeiro, qual é a atividade típica das crianças? A resposta é muito simples. As crianças brincam.

O que é brincar?

Brincar é uma atividade não produtiva. Ela não visa a produção de qualquer objeto.

Mas por que as crianças brincam, se isto não produz nada? Novamente, a resposta é simples. $\mathrm{O}$ brincar náo produz objetos, mas proporciona prazer. Se você acha esta palavra muito carregada de tons hedonísticos, pode substituí-la por "alegria", que soa de forma mais contrita. Talvez a natureza do brincar se aclare se nos lembrarmos da distinçẫo feita por Agostinho entre coisas que são para serem usadas e coisas para serem desfrutadas. Quando uso algo, este algo é sempre um meio para outra coisa, é um instrumento para a minha atividade produtiva, esteja eu usando palavras, objetos ou pessoas. Quando desfruto de alguma coisa, por outro lado, esta coisa é sempre um fim em si mesma. É isto que o brinquedo é: um fim em si mesmo, uma proposta de alegria - ele proporciona prazer. ${ }^{28}$

Rubem Alves, influenciado pela leitura feita por Huizinga ${ }^{29}$ sobre a importância do jogo (enquanto brincadeira) nas culturas humanas, afirma:

Huizinga, em seu Homo ludens, vai mais além, sustentando que o jogo não pode ser entendido como uma coisa entre outros dados da cultura. "Aqui", diz

fazê-la dormir, distrai-la em suas muitas internaçôes. Daí surgiu a vocação do contador de estórias para crianças (Junior, É uma pena não viver. Uma biografia de Rubem Alves, 274-284).

${ }^{28}$ Alves, $A$ gestação do futuro, 95-96, ênfases do original.

${ }^{29}$ Huizinga, Homo ludens. O jogo como elemento da cultura, 5. 
ele, "estamos lidando com uma categoria primária da vida" (Johan Huizinga, Homo ludens, p. 5) ${ }^{30}$. Náo é a cultura que produz o jogo, e sim este que produz a cultura. Por isso, a cultuar náo pode ser inteiramente compreendia senáo $s u b$ specie ludi31. Com efeito, se no ato criador da cultura descobrimos o homem preocupado em estabelecem uma ordo amoris, e se no jogo o encontramos tentando produzir uma ordem que proporcione o prazer, náo podemos evitar a conclusão de que estas são expressões de uma mesma dinâmica. ${ }^{32}$

$\mathrm{Na}$ sequência de sua elaboração, Rubem Alves afirma: "Huizinga está certo. $\mathrm{O}$ jogo não consiste num meio para um determinado fim. Ele proporciona prazer, e é o que basta. Feito a magia, encontra satisfação na representação de seu objeto" ${ }^{33}$.

Esta espiritualidade erótica, do brinquedo e da brincadeira, da subversão da lógica do poder, vivencia a experiência do sagrado, do sublime, da transcendência, de Deus, não a partir de repetiçâo de fórmulas confessionais elaboradas a partir de critérios metodológicos racionalistas, nem do sofrimento auto imposto, nem de práticas tradicionais da piedade e da devocionalidade popular cristá, consagrada pelo uso na tradição ocidental há séculos. Conforme Alves,

Será o jogo, o brinquedo, uma insanidade? Obviamente, se o julgamento da sanidade estiver determinado pelo sistema dominante. Os valores do brinquedo requerem a abolição do mundo adulto. Pode o jogo ser desprezado só porque é jogado pelos sem-poder? Apenas se você chama de insanidade as tentativas de voar empreendidas por um pássaro de asas feridas. O que é insano não é o seu sofrimento, os seus desajeitados esforços para voar, e sim é insana a máo que lhe partiu as asas. A verdade do jogo se tornará história quando a impotência se converter em poder e o que agora é poder for reduzido à impotência. "A menos que você se torne uma criança, jamais entrará no reino dos céus". A menos que você desista da presente ordem de coisas e se torne criativo, não viverá para ver o futuro. Estará condenado à extinção. ${ }^{34}$

No já mencionado texto "Sobre deuses e caquis", Rubem Alves também desenvolve sua compreensão da teologia, nem tanto com uma reflexão racional sobre a fé, mas como uma estesia erótica da vida. Algumas citaçóes serão pinçadas do referido

\footnotetext{
${ }^{30}$ A referência de Rubem Alves sem dúvida é à versão em inglês da obra de Huizinga, originalmente escrita em holandês.

${ }^{31}$ A expressão sub speciel udi ("sob a perspectiva do lúdico") em latim no original, foi criada por Rubem Alves como uma espécie de paráfrase da conhecida expressão sub specie aeternitatis ("sob a perspectiva da eternidade"), isto é, o que é universalmente verdadeiro, cunhada pelo filósofo holandês de origem portuguesa Baruch (Bento) Spinoza no século XVII.

32 Alves, A gestação do futuro, 99.

${ }^{33}$ Ibid., 102.

${ }^{34}$ Ibid., 107.
} 
texto, e pode-se observar que têm como linha mestra que as une a ênfase na alegria, no prazer, no exercício da teologia e, por extensão, na vivência da espiritualidade:

Teologia é uma brincadeira, parecida com o jogo encantado das contas de vidro que Hermann Hesse descreveu, algo que se faz por puro prazer, sabendo que Deus está muito além de nossas tramas verbais.

Teologia não é rede que se teça para apanhar Deus em suas malhas, porque Deus não é peixe, mas Vento que não se pode segurar...

Teologia é rede que tecemos para nós mesmos, para nela deitar o nosso corpo.

Ela não vale pela verdade que possa dizer sobre Deus (seria necessário que fôssemos deuses para verificar tal verdade); ela vale pelo bem que faz à nossa carne.

Ah! Pensam que sou herege... Nada disto. Estou apenas repetindo coisa muito velha, esquecida, da tradição protestante, que diz que "conhecer a Cristo é conhecer os seus benefícios" ${ }^{35}$ : de Deus, o único que podemos saber é o bem que faz ao nosso corpo. Com o que concorda o sábio Riobaldo: "Como não ter Deus? Com Deus existindo, tudo dá esperança, o mundo se resolve. Mas, se não tem Deus, há-de a gente perdidos no vai-vem, e a vida é burra. E o aberto perigo das grandes e pequenas horas... Tendo Deus, é menos grave se descuidar um pouquinho, pois, no fim, dá certo. Mas, se não tem Deus, entâo, a gente não tem licença para coisa nenhuma”.

Aqui se resume a teologia; o resto são floreios.

Há palavras que moram na cabeça e são boas para serem pensadas. Com elas se faz a ciência.

Mas há palavras que moram no corpo, e são boas para serem comidas. Chegam à carne sem passar pela reflexáo.

Magia. Ou poesia, que é a mesma coisa.

Teologia é um brinquedo que faço. Por que faço este jogo? Pelas mesmas razóes que jogam todos os jogos. Puro prazer.

É possível plantar jardins, pintar quadros, escrever poemas, jogar xadrez, cozinhar, fazer teologia... Claro que um jogo não exclui o outro. Alguns dirão que isto não é coisa séria. Teologia é um exercício de beleza e de humildade. Brincamos, como a própria Santíssima Trindade que, nos jogos intelectuais do venerável Santo Agostinho, só fazia uma coisa, nas transasintratrinitárias: brincar. Auto-erotismo.

O diabo está sempre vestido de paletó e gravata e, a se acreditar em Nietzsche, ele nem sabe contar piadas e nem sabe dançar: é o espírito da gravidade. Já com Deus é o contrário, porque a oração começa com o riso. ${ }^{36}$

\footnotetext{
${ }^{35}$ Rubem Alves se refere a um dito de Felipe Melanchton (1497-1560), reformador luterano alemão. Cfr. O’Donnell, Introdução à teologia dogmática, 98.

${ }^{36}$ Alves, "Sobre deuses e caquis”, 41-42. Observe-se a frase “... porque a oração começa com o riso”. Esta frase é de autoria do teólogo protestante estadunidense Richard Niehbur (1894-1962), e aparece como epígrafe de Alves, A gestação do futuro.
} 
O jovem teólogo luterano brasileiro Iuri Andreas Reblin analisa com propriedade o texto "Sobre deuses e caquis":

Em "Sobre deuses e caquis", Rubem Alves reafirma o espírito lúdico-poético que consolidou sua forma de compreender a teologia. Todos os elementos se fazem presentes: Deus é um mistério que não se pode apreender; a teologia não é um compêndio divino, mas é brinquedo e brincadeira, rede e tapete, feitiçaria e encantamento poético, música, morango, celebração do Vazio, exercício de beleza e humildade, todos destinados a saciar o corpo, a amenizar a saudade e a proporcionar o prazer e a beleza. Em todo o texto perpassa a oposiçáo a qualquer tipo de aprisionamento do divino, inclusive por meio do ato de crer. É sob a aura da certeza que inquisiçóes são feitas e hereges são queimados. Diante disso, Rubem Alves proporá o espírito lúdico e poético como característica evidente e inerente à teologia. ${ }^{37}$

Em Pai nosso. Meditaçôes, Rubem Alves apresenta sua tradução do texto da "Oração Dominical", que é efetivamente uma releitura na perspectiva da espiritualidade estético-erótica. Nesta releitura, a súplica "venha o teu Reino" é assim traduzida:

Traze-nos as coisas boas em que tens prazer:

O jardim

As fontes

As crianças

O pão e o vinho

Os gestos ternos

As mãos desarmadas

Os corpos abraçados... ${ }^{38}$

Ao formular ao longo dos anos sua espiritualidade estético-erótica, Rubem Alves não se preocupa em absoluto com a correção doutrinária. Mas esta releitura da espiritualidade, e mais ainda, da própria tradição cristã, não pode ser considerada heterodoxa. Com uma linguagem ousada, diferente da tradicional, Alves apresenta sua visão de Deus e da vivência da espiritualidade na radicalidade de um relacionamento profundo com o Eterno: "Se Deus deseja que tenhamos prazer nas coisas boas que ele nos dá, temos de nos esquecer do seu nome, para gozar das suas dádivas" ${ }^{39}$. E em outro lugar,

Ó Deus! Quem és tu?

Que nomes moram no teu mistério sem fim?

Ninguém jamais te viu.

\footnotetext{
${ }^{37}$ Reblin, Outros cheiros, outros sabores... O pensamento teológico de Rubem Alves, 177-178.

${ }^{38}$ Alves, Pai nosso. Meditaçôes, 5.

${ }^{39}$ Ibid., 53.
} 
Passas como o Vento, e só ficam as marcas da tua passagem, gravadas na memória: o sentimento de beleza, o sentimento de tristeza, o corpo que espera, sem certeza, com um poema na carne..$^{40}$

\section{Conclusão}

Em Rubem Alves a espiritualidade não é platônica, da alma, mas é, como toda sua teologia, do corpo. Daí a dimensão erótica desta espiritualidade, que vivenciaram o transcendente nas experiências estéticas, na estesia, nos prazeres e nas alegrias do dia a dia da vida:

Não, não quero homens desencarnados. Que os corpos sejam ressuscitados. Não, não quero o fim do mundo, dos bichos, das árvores, dos mares, da brisa. Tudo isso é muito bom. Que tudo seja redimido. A terra ainda há de ser um lugar de riso e de brinquedo. ${ }^{41}$

Profundamente influenciado pela distinção agostiniana entre as coisas úteis e as da fruição, Alves desenvolve sua própria compreensão de espiritualidade ${ }^{42}$, na qual no desfrute dos prazeres, na sensualidade - enquanto estesia, o que se sente - há um encontro com o Absoluto. Este encontro não se dá em uma dimensão etérea, mas nesta terra. Nas palavras do próprio Alves,

Abro o livro De doctrina christiana. Ele escreve contemplando o Paraíso: medita sobre a ordem eterna que regular o prazer e a alegria [...] O tema: "Algumas coisas são para serem fruídas, outras para serem usadas, e outras ainda há que são para serem fruídas e usadas. As coisas que são para serem fruídas nos tornam felizes. As coisas que são objetos de uso nos ajudam em nossos esforços na direção da felicidade, de forma a podermos obter as coisas que nos tornam felizes e, assim, nelas descansar". [...]. Entre os textos de sabedoria está esse curto parágrafo de Agostinho. Nenhum outro texto contribuiu tanto para simplificar e ordenar minhas ideias quanto esse. Quem o entender terá entendido a organização do meu pensamento, naquilo que ele tem de mais simples. $\mathrm{O}$ tema foi santo Agostinho que enunciou. Mas o meu texto não será exegético. Na exegese buscase compreender o mais fielmente possível o pensamento do autor: apresenta-lo ao leitor de forma transparente. O que vou dizer, entretanto, nasce de uma inspiração culinária e antropofágica. "Para comer meus próprios semelhantes, eis-me sentado à mesa". Leio, como o texto de santo Agostinho, e aquilo que agora escrevo é santo Agostinho transubstanciado em Rubem Alves. Já não é o pensamento de Agostinho; é o meu próprio pensamento. Escrever com sangue, o meu sangue... ${ }^{43}$

\footnotetext{
${ }^{40}$ Ibid, 21.

${ }^{41} \mathrm{Idem}$, Creio na ressurreição do corpo, 28.

${ }^{42}$ Idem, Variaçöes sobre o prazer, 93-112.

${ }^{43}$ Ibid., 93-94.
} 
Um dos textos em que Rubem Alves explica sua espiritualidade erótica de maneira mais explícita é em "Promessas", uma das crônicas da coletânea $A$ festa de Maria. A citação, conquanto longa, por conta de sua lucidez e argúcia, merece ser reproduzida:

Não ligo para aquilo que os meus inimigos pensam de mim. O que eles pensam nada revela a meu respeito - mas diz muito sobre as condiçốes do seu trato digestivo. Nietzsche dizia que havia pessoas que não gostavam dele porque suas palavras eram fogo para suas bocas. Mas palavras, como as pimentas, podem ser fogo na boca e fogo em outro lugar [...]. Assim, não ligo alguém pensar mal de mim.

Mas se os meus amigos pensarem mal de mim - isso sim vai me causar sofrimento. Se pensam mal de mim sendo meus amigos, isso quer dizer que existe uma pitada de verdade nos seus pensamentos. Os pensamentos dos amigos são espelhos. Aí vou ficar com vergonha, e vou começar a fugir da presença deles.

Deus é feito a gente. Não sofre nem um pouco com aquilo que o Diabo e sua gangue pensam dele. Mas o caso é diferente quando o que está em jogo sáo calúnias e vilezas que dele pensam -quem diria?- justamente aqueles que se dizem seus amigos [...].

Se você não está entendendo o que estou dizendo, trato de explicar.

Quando a gente dá uma coisa a gente está dizendo o que pensa do outo que recebe o presente. Dou água para a planta porque sei que planta gosta de água. Dou um osso para um cachorro porque sei que cachorro gosta de osso. Dou alpiste para um passarinho porque sei que passarinho gosta de alpiste.

Isso vale também para os presentes que damos às pessoas [...]. Um CD de música clássica diz que o outro, tal como ele existe na minha cabeça, é um apreciador de música erudita. Se o CD for de sax-jazz já a imagem do outro será diferente, mais sensual. Um livro de poesia dirá ao outro que ele (ou ela) é uma pessoa sensível e amante do silêncio. Panelas, ferramentas, brinquedos, echarpes, cuecas de seda, sutiâs de rendinha, um livro de arte erótica, uma garrafa de vinho, Bíblias e terços, caixas de bombons: cada um desses presentes diz ao outro o que penso dele.

Deus também merece presentes. Deus também quer ficar feliz. As pessoas que dizem gostar dele tratam de dar-lhe presentes (como os Magos) - os melhores, os que lhe darão maior prazer. Presentes que farão Deus sorrir de felicidade, presentes para fazer Deus voltar a ser criança! O presente que dou deve ser a realização do desejo do outro. E quais são os desejos de Deus - a se acreditar nos que lhe são oferecidos?

Antigamente os mais devotos, para fazer Deus ter prazer, autoflagelavam-se com chicotes e coisas pontudas [...]. Na casa de presentes a Deus se encontram, por exemplo, as seguintes opçóes: subir, de joelhos, o caminho até a igreja do Pe. Cícero; subir, de joelhos, a escadaria da Igreja da Penha; arrastar uma cruz, a pé, por 50 quilômetros; ficar sem comer por três dias; abster-se de beber cerveja por todo um mês; não tomar coca-cola por nove meses; não transar ou não se masturbar até que a graça seja concedida. 
O que dizem tais presentes sobre o caráter de Deus? Dizem que ele não é Deus, é um ser monstruoso, sádico, que fica feliz quando nós sofremos, corrupto, concede graças a troco de dor [... ]. Portanto, com um pedido de perdão por tanta ofensa, sugiro que, na passagem do ano, façamos promessas bonitas a Deus, promessas que digam que o achamos normal e bonito como nós. Ele não é sádico. Não tem orgasmos quando nós sofremos. Ele sofre quando sofremos e dá risadas quando damos reisadas. Assim, se oferecermos presentes de felicidade ele ficará feliz e voltará. Como exemplo aqui vão algumas das promessas que farei.

Vou andar diariamente, sem obrigação ode fazer exercício, por algum bosque ou jardim deste universo maravilhoso, por puro prazer. Vou comprar uma cachorrinha cocker-spaniel. Vou gastar tempo observando o voo dos pássaros, a forma das nuvens, a folhagem das árvores. Vou ver de novo $O$ carteiro e o poeta. Vou fugir do agito, do ruído, da confusão. Vou cultivar a solidão e o silêncio: um espaço sagrado. Vou fazer um jardim zen, com água e sinos que o vento toca. Vou ouvir muita música, canto gregoriano, Bach, Beethoven, Mahler, Cesar Franck. Vou ler o Fernando Pessoa inteiro. Vou aprender a cozinhar. Vou receber os amigos. Vou beber cerveja, vinho, Jack Daniels. Vou brincar com coisas e com pessoas.

Que Deus me ajude. E que ele se alegre com minhas promessas (Alves, 1999, 93-97, ênfases do autor). ${ }^{44}$

Esta espiritualidade pode ser interpretada por alguns como alienada e/ou alienante. Mas esta não é a melhor maneira de interpretar a espiritualidade estético-erótica de Rubem Alves. Antes, esta deve ser vista como um protesto contra a loucura dos que querem o poder pelo poder, dos que se rendem às imposiçóes implacáveis do deus mercado, dos que se julgam melhores que o "outro", dos que se iludem pensando que podem manipular o Eterno através de sua moralidade ou de sua ortodoxia teológica. A espiritualidade estético-erótica é um convite a um mergulho nas águas profundas do mistério da escandalosa e absoluta graça de Deus.

Rubem Alves sonhou com uma espiritualidade da alegria e da estesia. Desta maneira, concordou com Nietzsche (um dos pensadores com quem mais extensamente dialogou) que, em um de seus aforismos famosos, coloca na boca de Zaratustra a afirmação que só poderia crer em um Deus que soubesse dançar...

${ }^{44}$ Idem, A festa de Maria, 93-97. 


\section{Referências}

Alves, Rubem. A festa de Maria (4. ${ }^{\mathrm{a}}$ ed.). Campinas: Papirus, 1999. . A gestação do futuro. Campinas: Papirus, 1985. . A Theology of Human Hope. New York (NY): Corpus Books, 1969.

. Creio na ressurreição do corpo. Meditaçóes (2. ${ }^{\mathrm{a}}$ ed.). Rio de Janeiro: Centro Ecumênico de Documentação e Informação, 1984.

. Da esperança. Campinas: Papirus, 1978.

. O enigma da religião. Campinas: Papirus, 1984.

. O que é religião. São Paulo: Brasiliense, 1984.

. O suspiro dos oprimidos (2.a ed.). São Paulo: Paulinas, 1987.

. Pai nosso. Meditaçôes (6.a ed.). São Paulo: Paulus, 1987.

. Protestantismo e repressáo. São Paulo: Ática, 1982.

. Religião e repressáo. São Paulo: Loyola, 2005.

. "Sobre deuses e caquis". In Da esperança, por R. Alves, 41-42. Campinas: Papirus, 1987.

. Tomorrow's Child. New York (NY): Harper \& Row, 1972.

- Variaçóes sobre a vida e a morte ou o feitiço herético-erótico da teologia. São Paulo: Loyola, 2005.

- Variaçôes sobre o prazer (Santo Agostinho, Nietzasche, Marx e Babette). São Paulo: Planeta, 2012.

Boff, Clodovis. Teologia e prática - teologia do político e suas mediaçôes. Petrópolis: Vozes, 1978.

Butzke, Paulo Afonso. "Espiritualidade". Em Dicionário brasileiro de teologia, editado por Fernando Bortolleto Filho, J. C. de Souza e N. Kilpp, 387-390. São Paulo: ASTE, 2008.

Caldas, Carlos. "A polifonia e o ipê-amarelo: anotaçóes sobre o 'primeiro' Rubem Alves como leitor de Dietrich Bonhoeffer". Estudos teológicos 54, Vol. 2 (2014): 271-283.

Casaldáliga, Pedro e José Maria Vigil. Espiritualidade da libertação (4. ${ }^{a}$ ed.). Petrópolis: Vozes, 1996. 
Cervantes-Ortiz, Leopoldo. A teologia de Rubem Alves: poesia, brincadeira e erotismo. Campinas: Papirus, 2005.

Cox, Harvey. A festa dos folioes. Petrópolis: Vozes, 1974.

Dal Corso, Marco. Rubem Alves. Collana pensiero teologico. Brescia: Morcelliana, 2016.

Galilea, Segundo. Espiritualidade da libertação. Petrópolis: Vozes, 1975.

Gutiérrez, Gustavo. Beber em seu próprio poço. Itinerário espiritual de um povo. São Paulo: Loyola, 2000.

Huizinga, Johanes. Homo ludens. O jogo como elemento da cultura (5. ${ }^{\mathrm{a}}$ ed.). São Paulo: Perspectiva, 2008.

Junior, Gonçalo. É uma pena não viver. Uma biografia de Rubem Alves. São Paulo: Planeta, 2015.

Mondin, Battista. Os teólogos da libertação. São Paulo: Paulinas, 1980.

McIntosh, Mark A. Mystical Theology. London: Blackwell Publishers, 1998.

O’Donnell, John. Introdução à teologia dogmática. São Paulo: Loyola, 1999.

Puleo, Mev. The Struggle is One. Voices and Visions of Liberation. New York (NY): State University of New York Press, 1994.

Reblin, Iuri Andréas. Outros cheiros, outros sabores... O pensamento teológico de Rubem Alves. São Leopoldo: Oikos Editora e Faculdades EST, 2009.

Smart, Ninian. Dimensions of the Sacred. An Anatomy of World's Beliefs. Berkeley (CA): University of California Press, 1996. 